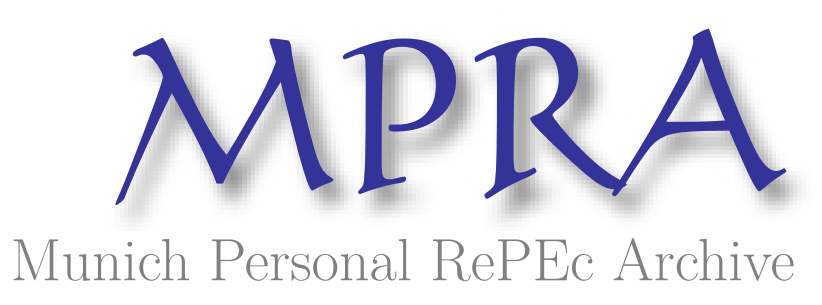

\title{
Does Monetary Policy Matter For Trade?
}

Chong, Terence Tai Leung and Wong, Kin Ming

12 April 2015

Online at https://mpra.ub.uni-muenchen.de/63502/

MPRA Paper No. 63502, posted 07 Apr 2015 07:43 UTC 


\title{
Does Monetary Policy Matter For Trade?
}

\author{
Kin-Ming Wong and Terence Tai-Leung Chong* \\ Department of Economics \\ The Chinese University of Hong Kong
}

$1 / 4 / 2015$

\begin{abstract}
:
There is a large literature on the effect of exchange rate arrangements on trade. The monetary policy used in the floating exchange rate regime, however, is usually ignored and unidentified in the empirical studies. This makes the effect of alternative monetary policy regimes on trade remains largely unknown. This paper sheds light on this area by examining the effect of two well-defined monetary policy regimes, namely exchange-rate targeting and inflation targeting regimes, on bilateral and multilateral trade. Our result suggests a moderate positive effect of inflation targeting policy on bilateral trades between two inflation targeting countries. This effect of inflation targeting, even much moderate than the effect of currency union and a fixed exchange rate at the bilateral level, could exist in the bilateral trades with a large number of trading partners under the same regime. This implies that inflation targeting regime may not have a lower level of multilateral trade than exchange-rate targeting regime. We further support this view with an analysis of multilateral trade.
\end{abstract}

JEL Classifications: E42, E52, E58, F14

Keywords: Monetary Policy Regimes; Inflation Targeting; Exchange-rate Targeting; Gravity Model; Trade

\footnotetext{
* Corresponding author: Terence Tai-Leung Chong, Department of Economics, The Chinese University of Hong Kong, Shatin, N.T., Hong Kong. Email: chong2064@ cuhk.edu.hk.
} 
“..... for both trade and welfare a comparison across exchange-rate systems depends crucially on precisely how each system is implemented. For example, it can make a big difference whether a one-side or cooperative peg is adopted, and how the degree of policy flexibility under a float is used to respond to idiosyncratic demand and supply shocks."

Bacchetta and Van Wincoop (2000)

\section{Introduction}

There is a large literature on the effect of exchange rate arrangement on trade. The influential work of Rose (2000) and other subsequent studies of Rose and Van Wincoop (2001a), Glick and Rose (2002) and Frankel and Rose (2002) show that there is a strong positive effect of a common currency on trade. This conclusion is supported by Klein and Shambaugh (2006) and Adam and Cobham (2007) using more detailed classifications on exchange rate systems. In addition, Klein and Shambaugh (2006) find that a fixed exchange rate in other more general forms also expands trade. Their finding suggests a positive effect of a fixed exchange rate on trade between a base country and a country that pegs to it.

These evidences suggest that exchange rate targeting policy, either in the form of currency union or others, could benefit trade. The monetary policy used in the alternative floating exchange rate regime, on the other hand, is usually ignored in these studies. The importance of monetary policy strategies in the comparison of trade across exchange-rate regimes, however, is highlighted by Bacchetta and Van Wincoop 
(2000). In contrast to partial equilibrium models which usually formulate exchange rate volatility as exogenous, the full equilibrium approach in Bacchetta and Van Wincoop (2000) models exchange rate volatility as a result of underlying monetary shock. The standard argument for the negative impact of exchange rate volatility on trade under a floating rate could therefore be compensated by the offsetting effect of monetary shock on demand in the full equilibrium model. Bacchetta and Van Wincoop (2000) show that a fixed exchange rate does not necessarily lead to more bilateral trades under certain assumptions, and the comparison of trade across exchange-rate regimes turns out to depend crucially on how the degree of monetary policy flexibility under a floating rate is used to respond to shocks. Unfortunately, empirical study on the possible effects of monetary policies on trade is absent.

This paper sheds light on this area by examining the effect of alternative monetary policy regimes on trade based on a comprehensive de facto classification of monetary policy framework from Wong and Chong (2014). The two well-defined monetary policy regimes - inflation targeting and exchange-rate targeting regimes classified in Wong and Chong (2014), provide an opportunity to explore whether flexibility of monetary policy under a floating exchange rate matters for trade. In particular, this paper studies the effect of inflation targeting policy on trades between two inflation targeting countries, which remains unexplored in the existing literature.

Results of this paper support the previous findings on the strong positive effect of exchange rate targeting policy on trade. In addition, this paper reveals a moderate positive effect of inflation targeting policy on bilateral trades between two inflation targeting countries. Unlike the single direct peg relationship in an exchange-rate 
targeting policy, an inflation targeting country could trade with many more countries under the same regime. This moderate effect is therefore accumulative at the multilateral level, further suggesting that inflation targeting regime may not have a lower level of multilateral trade than exchange-rate targeting regime. This view is supported by the analysis of multilateral trade under the two monetary policy regimes.

The rest of this paper is organized as follows. The methodology, classification of monetary policy regimes and data are discussed in section 2 . Section 3 presents the main results of the gravity model using bilateral data. Section 4 discusses the implication of the effects of bilateral trade on multilateral trade and provides an empirical analysis of the trade performance across alternative monetary policy regimes. Section 5 concludes.

\section{The Methodology and Data}

\subsection{The Gravity Model}

This paper investigates the effect of monetary policy on bilateral trade using the standard gravity model:

$$
\text { ltrade }_{i, j, t}=\alpha_{0}+\beta_{1} \operatorname{lprgdp}_{i, j, t}+\beta_{2} \text { ldist }_{i, j}+\beta_{3} c t y+\theta X_{i, j, t}+\gamma M P_{i, j, t}+\varepsilon_{i, j, t}
$$

where 
ltrade is the natural logarithm of trade between two countries $i$ and $j$ at time $t$ in real term $^{1}$

lprgdp is the natural logarithm of the product of real GDP of the two countries and ldist is the natural logarithm of their distance.

The variable cty is a vector of dummies for all countries in the data in which two dummies representing the trading countries in a bilateral trade observation are equal to 1.

A discussion on the theoretical foundation for the use of these variables is offered in Anderson and Van Wincoop (2003). In their model, the distance between trading countries represents a proxy of trading costs and the country-specific dummies are an alternative to replace the "multilateral resistance" of different countries. Empirically, a set of control variables as represented by $X$ are included in the estimations. This paper follows the literature to include a set of commonly-used control variables which are the dummies for common language, the existence of a free trade agreement, trading countries with the same colonizer, a colony-colonizer relationship and a variable for bilateral exchange rate volatility.

The effect of monetary policy regimes on trade is measured by $\gamma$ and $M P$ describes the monetary policy relationship of the two countries at the bilateral level. Country-year observations are classified in exchange-rate targeting and inflation targeting regimes in Wong and Chong (2014). The interactions of the two monetary policy regimes are categorized in five monetary policy relationships at the bilateral level which are currency union, direct peg, indirect peg, both inflation targeting and others in this

\footnotetext{
${ }^{1}$ The trade values in real term are estimated with the nominal trade values deflated by US inflation.
} 
study. Since bilateral exchange rate volatility is included in the estimations, it is important to note that the coefficients of these monetary policy relationships are their effect on trade after controlling their impact through exchange rate volatility.

Three of the monetary policy relationships examined in this study, namely currency union, direct peg and indirect peg, have been studied in the earlier literature. Currency union is regarded as the strongest form of exchange-rate targeting regime and is usually identified separately. It is argued that the reduction in transaction costs and the serious commitment to a fixed rate achieved by the use of a common currency may not be otherwise achieved in other forms of exchange-rate targeting. Empirical evidence also supports that the effect of a currency union membership on trade is much stronger than that other exchange-rate targeting arrangements. The effect of traditional currency unions such as the CFA franc zone and the Caribbean Currency Union is very strong and the positive effect on trade ranges from an increase of $80 \%$ to $300 \%{ }^{2}$. The trade effect of the European Monetary Union (EMU) is arguably smaller with an estimated effect between $6 \%$ and $46 \%^{3}$. This study follows the widely-adopted approach in Rose (2000), Rose and Van Wincoop (2001) and others to define currency union as (i) a country which does not issue its own currency and uses that of another, or (ii) uses a multilateral currency of a monetary union. This also includes a few cases where there is a considerable currency substitution between two currencies with a long-term peg at par.

Exchange rate fixed without using a common currency could also have an effect on

\footnotetext{
${ }^{2}$ For example, see Rose (2000), Rose and Van Wincoop (2001), Glick and Rose (2002) and Frankel and Rose (2002).

${ }^{3}$ For example, see Micco et al. (2003) and Berger and Nitch (2008).
} 
trade beyond that of reduced volatility. For example, Klein and Shambaugh (2006) argue that the presence of a peg could indicate a strong likelihood that the exchange rate will be close to constant over a period of time in the future. They offer empirical evidence on a large and significant effect of a fixed exchange rate and the bilateral trade between a base country and a country that peg to it expands by nearly $30 \%$. Based on the coordinated multilateral exchange-rate targeting under the gold standard, Lopez-Cordova and Meissner (2003) also find an effect with similar magnitude between countries under the gold standard. Similar to Klein and Shambaugh (2006), a country is determined to have a direct peg with a certain base country in a given year when they have the lowest bilateral exchange rate volatility among a group of base currencies ${ }^{4}$ in this study. An indirect peg, on the other hand, exists for two exchangerate targeting countries pegging to the same base currency ${ }^{5}$. Estimations in Klein and Shambaugh (2006) show that indirect peg has a negative impact on trade even though the effect is not statistically significant.

The new classification of Wong and Chong (2014) provides an opportunity to estimate the effect of inflation targeting policy on trade. In particular, the effect of inflation targeting policy on bilateral trade between two inflation targeting countries is studied. Since foreign exchange intervention is always an important channel for inflation targeting countries to control inflation, it is possible that trade between two inflation targeting countries is encouraged through a expectedly more stable exchange rate following the argument in Klein and Shambaugh (2006). To investigate the potential

\footnotetext{
${ }^{4}$ A list of base currencies is available in Wong and Chong (2014) which in turn is mainly based on the list in Levy-Yeyati and Sturzenegger (2005) and Rose (2000).

${ }^{5}$ For a country which uses a multilateral currency such as the euro, it is considered to have an indirect peg to another country if the multilateral currency is being pegged by another country.
} 
trade effect empirically, trade between two inflation targeting countries is identified as "Both IT". All other bilateral monetary policy relationships other than the four categories are grouped as others and used as the base case in the estimations.

Early empirical studies on currency union were mainly based on results obtained from pooled OLS estimation. Even though a country pair fixed effect model is more robust with time-invariant omitted variables, the near absence of variations in the currency union status for countries in the early datasets has largely limited its use. For the later studies covering observations in longer period, the fixed effect model becomes a more common approach ${ }^{6}$. Other than the least squares method, Silva and Tenreyro (2006) and Tenreyro (2007) suggest a Poisson pseudo-maximum-likelihood (PPML) estimator based on the generalized method of moments approach to handle several biases including the sample selection problem in the usual log-linearized estimation. The empirical results obtained by PPML, however, are found to be highly consistent with the results from OLS estimations. The country pair fixed effect model is used as the main approach in this paper in view of its robustness and the long period of data covered in the dataset. Estimations by pooled OLS are also included for reference.

\subsection{The Classification and Data}

This study covers observations for the 228 countries reporting to the IMF over the post-Bretton Woods period from 1974 to $2009^{7}$. The classification of monetary policy

\footnotetext{
${ }^{6}$ For example, see Glick and Rose (2002) on currency union in general; Frankel (2008) and Berger and Nitsch (2008) on European Monetary Union and Klein and Shambaugh (2006) on various exchange rate arrangements.

${ }^{7}$ In some cases, data of a country may not be available since the country does not exist in the entire sample period. Out of the 228 countries reported in the list of IMF, 186 countries have been classified at
} 
regimes is based on Wong and Chong (2014), where country-year observations are grouped into two monetary policy regimes: exchange-rate targeting and inflation targeting according to the similarity in the observed volatility of the instrument variable, interest rate and two outcome variables, exchange rate and inflation rate using k-means cluster analysis. There are classifications used in similar studies with alternative methodology. For example, the classification used in Klein and Shambaugh (2006) is solely based on the behaviors of countries' official exchange rates. As argued by Levy-Yeyati and Sturzenegger (2005), however, such a strategy may misleadingly group countries with small shocks in a fixed exchange regime. Therefore, it is possible that the positive effect on trade found in Klein and Shambaugh (2006) comes from the occurrence of smaller-than-average $\operatorname{shock}^{8}$ rather than a direct peg relationship. The incorporation of a monetary policy instrument in the classification as in Wong and Chong (2014) could minimize this problem. The inclusion of inflation targeting as the alternative policy framework in the classification is also important. It is not uncommon for inflation targeting countries such as New Zealand, Finland, and Norway to maintain relatively stable currencies with heavy intervention in foreign exchange markets in order to achieve stable inflation. These observations are usually misleadingly classified as fixed exchange rate regime in the classification frameworks using a fixed versus floating rate system. Wong and Chong (2014), on the other hand, classify these observations as inflation targeting regime.

Data for currency unions and other variables in the gravity model including trade agreements, distances between countries, and dummies for common language,

\footnotetext{
least for one period.

${ }^{8}$ It is also possible that it is a direct effect of low exchange rate volatility if the relationship between exchange rate volatility and trade is nonlinear.
} 
common border, same colonizer, colonizer-colony relationship, number of islands, and landlocked are obtained from the dataset of Rose and Spiegel (2011) and extended with information from the World Bank, WTO, and corresponding central banks. The trade data is obtained from the Direction of Trade Statistics and real GDP data is sourced from the World Bank. Multilateral and bilateral exchange rate volatilities are measured as the average of absolute monthly changes in the exchange rate obtained from the International Financial Statistics.

\section{The Main Results}

\subsection{Baseline Estimations}

The summary statistics of five monetary policy relationships including currency union, direct peg, indirect peg, both inflation targeting, and others are reported in Table 1. The statistics in general are consistent with the conventional understandings. The currency union members are usually relatively small in economic size, closer to each other, more likely to share a common language, border, and from the same colonizer. As expected, countries within a currency union and under a direct peg relationship trade much more than countries of other relationships but the differences probably reflect the endogeneity of regime choice. Exchange rate volatility between currency union members is extremely low by definition ${ }^{9}$. Direct and indirect pegs are similar in terms of exchange rate volatility but later estimations show that their effects on trade are very different. Unsurprisingly, exchange rate volatility is highest among

\footnotetext{
${ }^{9}$ The exchange rate volatility between currency union members is non-zero as some countries may not join or form a currency union for the whole year period.
} 
inflation targeting countries.

Table 1. Summary Statistics on Bilateral Monetary Policy Relationship

\begin{tabular}{|c|c|c|c|c|c|}
\hline & EitheI & ne is Exch: & ge-rate Tar & ting & $\underline{\text { Both are }}$ \\
\hline & $\begin{array}{c}\text { Currency } \\
\text { Union }\end{array}$ & $\begin{array}{l}\text { Direct } \\
\text { Peg }\end{array}$ & $\begin{array}{c}\text { Indirect } \\
\text { Peg }\end{array}$ & Others & Targeting \\
\hline Total observations & 3,274 & 1,389 & 13,661 & 84,226 & 26,115 \\
\hline Number of switches & 127 & 552 & 7,570 & - & 330 \\
\hline Bilateral trade (in billions) & 1.25 & 1.36 & 0.09 & 0.15 & 0.56 \\
\hline Lprgdp & 46.74 & 52.54 & 47.74 & 49.11 & 50.46 \\
\hline Ldist & 6.61 & 8.34 & 7.82 & 8.22 & 8.30 \\
\hline Exchange rate volatility & 0.01 & 0.47 & 0.41 & 3.81 & 4.89 \\
\hline Common language & 0.72 & 0.49 & 0.32 & 0.19 & 0.23 \\
\hline Common border & 0.22 & 0.01 & 0.04 & 0.02 & 0.03 \\
\hline Common colony & 0.64 & 0.00 & 0.17 & 0.08 & 0.07 \\
\hline Colony & 0.01 & 0.13 & 0.01 & 0.02 & 0.03 \\
\hline Number of islands & 0.24 & 0.24 & 0.37 & 0.34 & 0.41 \\
\hline Number of landlockeds & 0.48 & 0.16 & 0.22 & 0.31 & 0.30 \\
\hline Free trade agreement & 0.64 & 0.08 & 0.33 & 0.23 & 0.33 \\
\hline
\end{tabular}

Estimation results of the gravity model are presented in Table 2. The baseline model is 
estimated under several econometric methods and results are reported in the first three columns. The first two columns are results estimated by traditional pooled OLS method where the estimation in the second column includes the country dummies to proxy for the multilateral resistance suggested in Anderson and Van Wincoop (2003). Results in the third column, on the other hand, are estimated with the fixed effect model to control any unobservable variables affecting trade at country pair level.

The estimation results are highly consistent with the existing literature. The signs of the control variables are in line with the theoretical gravity model as well as previous empirical studies. The estimated effects of several monetary policy relationships are qualitatively comparable to the findings in the literature. The country pair fixed effect model reports that currency union members trade nearly $40 \%$ more than the base case. As suggested in the fourth column, this effect is similar between the recently formed EMU and the traditional currency unions. Unsurprisingly, the estimated effect on the other traditional currency unions is statistically insignificant because of the lack of currency union membership variations in the fixed effect model $^{10}$.

Even though both direct and indirect peg relationships lead to relatively low exchange rate volatility between trading partners, their effects on trade are opposite. Similar to the results found by Klein and Shambaugh (2006), Table 2 reports that a direct peg is estimated to increase trade by $21 \%$. The indirect peg pair, however, trades about $14 \%$ less. This opposition supports the view in the literature that exchange rate arrangements are likely to influence trade through channels other than the realized

\footnotetext{
${ }^{10}$ On the other hand, Glick and Rose (2002) establish the statistically significance by tracing back their data to 1948 to include sufficient variations in the currency union membership for the fixed effect model estimation.
} 
exchange rate volatility. One of the possible explanations is that the expected exchange rate volatility under the indirect peg is much more uncertain as the relationship depends on the decision of the two pegging countries to maintain their pegs.

Table 2. Monetary Policy Relationships and Bilateral Trade

\begin{tabular}{|c|c|c|c|c|c|}
\hline & \multicolumn{2}{|c|}{ Pooled OLS } & \multicolumn{3}{|c|}{ Fixed Effect } \\
\hline & (1) & (2) & (3) & (4) & (5) \\
\hline \multirow[t]{2}{*}{ Currency union } & $0.61 * * *$ & 0.11 & $0.32 * * *$ & & $0.37 * * *$ \\
\hline & $(0.15)$ & $(0.15)$ & $(0.07)$ & & $(0.07)$ \\
\hline \multirow[t]{2}{*}{ EMU } & & & & $0.37 * * *$ & \\
\hline & & & & $(0.04)$ & \\
\hline \multirow[t]{2}{*}{ Other currency unions } & & & & 0.32 & \\
\hline & & & & $(0.25)$ & \\
\hline \multirow[t]{2}{*}{ Direct peg } & $0.67 * * *$ & $0.36 * * *$ & $0.19 * * *$ & $0.19 * * *$ & $0.57 * * *$ \\
\hline & $(0.08)$ & $(0.10)$ & $(0.06)$ & $(0.06)$ & $(0.07)$ \\
\hline \multirow[t]{2}{*}{ Indirect peg } & $-0.21 * * *$ & $-0.18 * * *$ & $-0.15 * * *$ & $-0.15 * * *$ & $-0.15 * * *$ \\
\hline & $(0.05)$ & $(0.04)$ & $(0.02)$ & $(0.02)$ & $(0.02)$ \\
\hline \multirow[t]{2}{*}{ Both IT } & $0.16^{* * *}$ & 0.03 & $0.06 * * *$ & $0.06 * * *$ & $0.07 * * *$ \\
\hline & $(0.03)$ & $(0.02)$ & $(0.01)$ & $(0.01)$ & $(0.01)$ \\
\hline \multirow[t]{2}{*}{ Exchange volatility } & -0.07 & -0.05 & $-0.04 * *$ & $-0.04 * *$ & $-0.04 * *$ \\
\hline & $(0.03)$ & $(0.03)$ & $(0.02)$ & $(0.02)$ & $(0.02)$ \\
\hline \multirow[t]{2}{*}{ Free trade agreement } & $0.18 * * *$ & $0.36 * * *$ & $0.32 * * *$ & $0.32 * * *$ & $0.32 * * *$ \\
\hline & $(0.04)$ & $(0.04)$ & $(0.03)$ & $(0.03)$ & $(0.03)$ \\
\hline \multirow[t]{2}{*}{ Lprgdp } & $1.11 * * *$ & $1.12 * * *$ & $1.16^{* * *}$ & $1.16^{* * *}$ & $1.16^{* * *}$ \\
\hline & $(0.01)$ & $(0.04)$ & $(0.04)$ & $(0.04)$ & $(0.04)$ \\
\hline \multirow[t]{2}{*}{ Ldist } & $-1.30 * * *$ & $-1.64 * * *$ & & & \\
\hline & $(0.03)$ & $(0.03)$ & & & \\
\hline \multirow[t]{2}{*}{ Common language } & $0.55 * * *$ & $0.46^{* * *} *$ & & & \\
\hline & $(0.05)$ & $(0.05)$ & & & \\
\hline
\end{tabular}




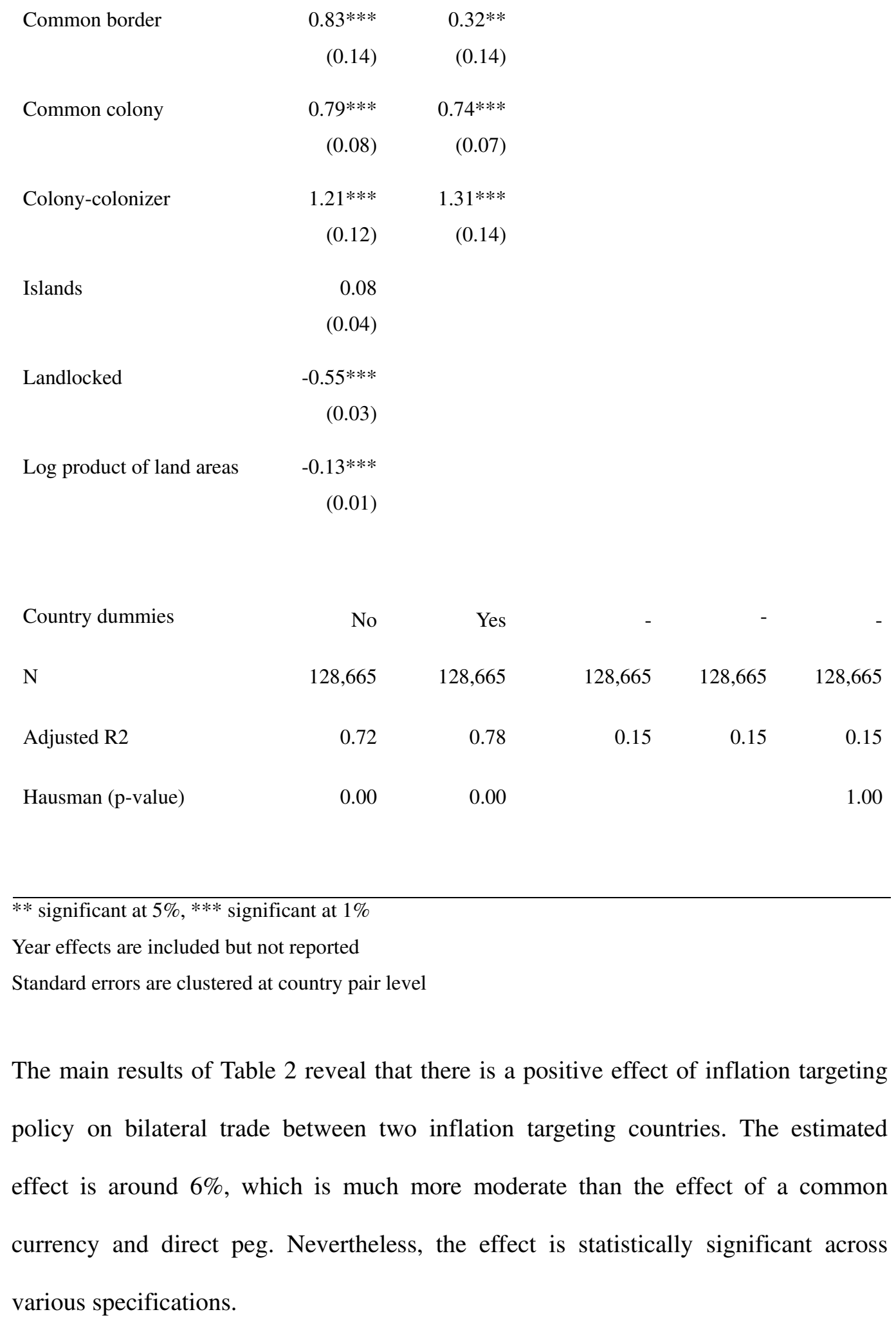

0.00

0.00

** significant at 5\%, *** significant at $1 \%$

Year effects are included but not reported

Standard errors are clustered at country pair level

The main results of Table 2 reveal that there is a positive effect of inflation targeting policy on bilateral trade between two inflation targeting countries. The estimated effect is around 6\%, which is much more moderate than the effect of a common currency and direct peg. Nevertheless, the effect is statistically significant across various specifications. 
Table 3. Comparisons of the Estimated Trade Effect of Currency Union and Direct Peg with Other Studies

\begin{tabular}{|c|c|c|c|}
\hline & $\begin{array}{l}\text { Data } \\
\text { Coverage }\end{array}$ & $\begin{array}{c}\text { Country Fixed } \\
\text { Effect Model } \\
\text { (Pooled OLS) }\end{array}$ & $\begin{array}{c}\text { Country pair } \\
\text { Fixed Effect } \\
\text { Model }\end{array}$ \\
\hline Estimated Coefficients on Currency Union & & & \\
\hline Baseline & 1974-2009 & $\begin{array}{r}0.11 \\
(0.15)\end{array}$ & $\begin{array}{r}0.32 \\
(0.07)\end{array}$ \\
\hline Excluding data after 1998 & 1974-1998 & $\begin{array}{r}1.01 \\
(0.21)\end{array}$ & - \\
\hline $\begin{array}{l}\text { Separate dummies for EMU and other } \\
\text { currency unions }\end{array}$ & 1974-2009 & $\begin{array}{r}0.86 \\
(0.19)\end{array}$ & - \\
\hline Excluding EMU data from the sample & 1974-2009 & $\begin{array}{r}0.88 \\
(0.18)\end{array}$ & - \\
\hline Rose and Van Wincoop (2001a) & $\begin{array}{r}\text { 1970-1995, } \\
5 \text {-year } \\
\text { interval }\end{array}$ & $\begin{array}{r}0.86 \\
(0.19)\end{array}$ & - \\
\hline Glick and Rose (2002) & 1948-1997 & $\begin{array}{r}1.30 \\
(0.13)\end{array}$ & $\begin{array}{r}0.59 \\
(0.05)\end{array}$ \\
\hline Klein and Shambaugh (2006) & 1973-1999 & $\begin{array}{r}1.23 \\
(0.16)\end{array}$ & $\begin{array}{r}0.32 \\
(\mathbf{0 . 1 3})\end{array}$ \\
\hline Estimated Coefficients on Direct Peg & & & \\
\hline Baseline & 1974-2009 & $\begin{array}{r}0.36 \\
(0.10)\end{array}$ & $\begin{array}{r}0.19 \\
(0.06)\end{array}$ \\
\hline Klein and Shambaugh (2006) & 1973-1999 & $\begin{array}{r}0.32 \\
(0.15)\end{array}$ & $\begin{array}{r}0.19 \\
(0.09)\end{array}$ \\
\hline Lopez-Cordova and Meissner (2003) & $\begin{array}{r}\text { 1870-1910, } \\
5 \text {-year } \\
\text { interval }\end{array}$ & $\begin{array}{r}0.28 \\
(0.13)\end{array}$ & $\begin{array}{r}0.15 \\
(0.08)\end{array}$ \\
\hline
\end{tabular}


Table 3 provides a comparison between the estimated effects in this paper and that in previous studies. In particular, the small and highly insignificant effect estimated on the currency union by the pooled OLS with country dummies (also called country fixed effect model (CFE)) is strikingly different from previous studies and is investigated with several sensitivity tests. Sensitivity tests on the CFE model reveal that the results are mainly distorted by the EMU observations which are not covered in the early studies using the CFE model. Once the distortion in EMU data is removed from various specifications, the estimated effect of currency union on trade becomes highly consistent with the existing literature. Results of the country pair fixed effect model, nevertheless, are similar across various studies.

\subsection{Instrument Variable Estimation}

To address the possible endogeneity of monetary policy regimes, the baseline model is estimated with an instrumental variable and results are presented in the last column of Table 2. As argued in Rose (2000), "trade considerations seem irrelevant when a country decides whether to join or leave a common currency area" and this argument is even stronger in this study with currency union observation including the EMU. Empirically, the endogeneity of currency union is also found to have no significant effect as suggested by the instrumental variables estimations. It is equally hard to argue that endogeneity exists for countries in indirect peg and inflation targeting regime. The main concern on the endogeneity of monetary policy regimes, therefore, rests on the direct peg relationship. It is possible that a country pegs its currency to another country due to a close trade relationship rather than the direct peg causes more 
trade.

The instrumental variable used in this paper follows the approach of Klein and Shambaugh (2006), which in turn draws on the insight of Tenreyro (2007). For two trading countries, the percentage of countries in country $j$ 's region that are directly pegged with country $i$ is used as the instrumental variable. To stabilize its exchange rate with neighbors, it is more likely for a country to have a peg with another country if more countries in its region choose to do so. This percentage, however, is unlikely to be correlated with trade between country $i$ and $j$. This percentage is therefore considered as an appropriate instrument ${ }^{11}$. As shown in last column, the result of the instrument variable estimation is similar to the baseline estimation of the fixed effect model in the third column. In particular, the moderate positive trade effect between inflation targeting countries remain statistically significant.

\section{An Analysis of the Trade Performance of Monetary Policy Regimes}

\subsection{The Implication of Results on Bilateral Trade}

In the gravity model estimation, inflation targeting policy is found to have a positive effect on bilateral trade with countries in the same regime. The effect is much more moderate than the effects on trade between currency union members and trade between countries in a direct peg. This result, however, does not necessarily imply a

\footnotetext{
${ }^{11}$ In practice, the percentage of countries in country j's region that are directly pegged with country $i$ and the percentage of countries in country i's region pegged to country $j$ are computed. The higher one of these two percentages is used as the instrumental variable.
} 
worse trade performance of inflation targeting regime at the multilateral level. The reason is that the moderate effect of inflation targeting policy could exist in the bilateral trades with a large number of trading partners in the same regime at the multilateral level. The trade creation effect of exchange-rate targeting policy under a direct peg, by contrast, is restricted to a single anchor country ${ }^{12}$. For example, in the year of 2005, Singapore in the inflation targeting regime was trading with the other 56 inflation targeting countries. Hong Kong which adopts an exchange-rate targeting policy with a currency board system could only maintain a direct peg relationship with the United States. Table 4 provides the statistics on the average number of bilateral monetary policy relationships in various monetary policy regimes. As shown in Table 4, the effect of inflation targeting on trade could be amplified 36 times for inflation targeting regime ${ }^{13}$. It should also be noted that the average number of members in a currency union is 7 , meaning that the positive effect of using a common currency is also applied on more than one bilateral trade.

\footnotetext{
${ }^{12}$ Countries issuing the base currencies, which are being pegged by others, could be in direct peg with more than one country. These countries, however, should be considered as exceptional cases and have least policy relevance.

${ }^{13}$ It is also interesting to note that inflation targeting countries also have the level of direct peg relationship comparable to exchange-rate targeting countries. It is because inflation targeting countries are usually pegged by a number of exchange-rate targeting countries.
} 
Table 4. Bilateral Monetary Policy Relationships and Monetary Policy Regimes

\begin{tabular}{|c|c|c|c|c|}
\hline & & \multicolumn{3}{|c|}{ Monetary Policy Regimes } \\
\hline & & Inflation Targeting & Currency Union & $\begin{array}{c}\text { Exchange-rate } \\
\text { Targeting (Non-CU) }\end{array}$ \\
\hline \multirow{5}{*}{ 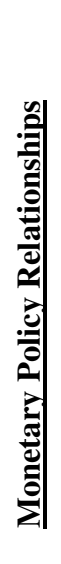 } & Both IT & 36.12 & 0.00 & 0.00 \\
\hline & Direct peg & 0.95 & 0.31 & 0.71 \\
\hline & Indirect peg & 0.00 & 8.38 & 10.06 \\
\hline & Currency & 0.00 & 6.89 & 0.00 \\
\hline & Others & 43.86 & 42.41 & 34.36 \\
\hline
\end{tabular}

$\overline{\text { Statistics reported in the table are the average number of monetary policy relationships in various }}$ monetary policy regimes at the bilateral trade level. For example, an inflation targeting country is trading with 36 other inflation targeting countries on average. The direct peg relationship in the inflation targeting regime is larger than zero as inflation targeting countries may be pegged by several other exchange-rate targeting countries. On the other hand, the average direct peg relationship is less than one in the exchange-rate targeting regime because issuing entities of some anchor currencies such as SDR and EMU do not exist in the trade statistics.

A naïve computation on the trade performance of monetary policy regimes using the average bilateral trade statistics in Table 1, the estimated effect of various monetary policy relationships on trade in Table 2 and the number of monetary policy 
relationships in different monetary policy regimes, suggest that currency union would have the most positive effect on multilateral trade in view of the strong effect on trade between its members and the moderate number of members in the currency union. Following the currency union, inflation targeting outperforms the non-currency union exchange-rate targeting regime with the amplified moderate effect on trade between countries in the inflation targeting regime. The actual performance of alternative monetary policy regimes, nevertheless, is an empirical issue to be discussed in the next section.

\subsection{An Analysis on Multilateral Trade}

Table 5 presents a summary of statistics on the two monetary policy regimes and their subgroups. In general, countries in the exchange-rate targeting regime have lower level of multilateral trade than inflation targeting regime and are smaller in both economic size and land area. Given that, a simple comparison of trade between two regimes may not be valid. The recently formed EMU and other traditional currency unions including the CFA franc zone in Africa and the Eastern Caribbean Currency Union exhibit similarities as well as differences. Compared to the inflation targeting regime and non-currency union exchange-rate targeting regime, both EMU and traditional currency unions are very durable. The EMU members, however, have an average gross domestic product over 150 times that of the members of traditional currency unions which are usually formed by small and developing economies. This suggests that factors determining trade between members of EMU and other traditional currency unions could be largely different and this probably explains the striking result on the currency union coefficient estimated with the FCE model in 
Table 2.

Table 5. Summary Statistics for Monetary Policy Regimes

\begin{tabular}{|c|c|c|c|c|c|}
\hline & \multirow{2}{*}{$\begin{array}{l}\text { Inflation } \\
\text { Targeting }\end{array}$} & \multicolumn{4}{|c|}{ Exchange-rate Targeting } \\
\hline & & Overall & Non-CU & EMU & Other CUs \\
\hline Total observations & 857 & 868 & 415 & 121 & 332 \\
\hline Number of switches & 442 & 355 & 339 & 13 & 1 \\
\hline Advanced economies & 437 & 171 & 47 & 121 & 3 \\
\hline \multicolumn{6}{|l|}{ Multilateral trade (in } \\
\hline billions) & 52.51 & 25.18 & 17.29 & 119.21 & 0.76 \\
\hline Real GDP (in billions) & 827.43 & 238.42 & 222.33 & 932.94 & 5.42 \\
\hline \multicolumn{6}{|l|}{ Effective exchange rate } \\
\hline volatility: & & & & & \\
\hline Nominal & $1.82 \%$ & $1.42 \%$ & $2.12 \%$ & $0.54 \%$ & $0.85 \%$ \\
\hline Real & $1.90 \%$ & $1.65 \%$ & $2.25 \%$ & $0.56 \%$ & $1.30 \%$ \\
\hline Land area (in '000 km²) & 1,352 & 642 & 1,164 & 204 & 149 \\
\hline Island & 0.20 & 0.26 & 0.13 & 0.03 & 0.51 \\
\hline Landlocked & 0.18 & 0.16 & 0.21 & 0.18 & 0.09 \\
\hline Duration of regime & 5 years & 10 years & 4 years & 8 years & 20 years \\
\hline
\end{tabular}


Table 5 also provides another hint that findings at the bilateral level do not necessarily extend to the multilateral level for the monetary policy regimes. Even though an exchange-rate targeting country could enjoy relatively low bilateral exchange rate volatility with its anchor country, its multilateral exchange rate volatility is higher than an inflation targeting country as is suggested in Table 5. Indeed, the results on the effect of exchange-rate targeting policy on multilateral exchange rate volatility are mixed. Evidences provided by Husain, Mody and Rogoff (2005), Klein and Shambaugh (2008) and many other studies support that the fixed exchange rate regime has a lower volatility in nominal and real multilateral exchange rate against the floating regime. Rose (2007), however, shows that the fixed exchange rate regime may not enjoy lower exchange rate volatility, instead it may suffer a higher volatility when compared to the inflation targeting regime based on a small sample. Table 6 presents some simple comparisons of exchange rate volatility between monetary policy regimes estimated with fixed effect model. Consistent with the literature, the results are mixed. Even though the exchange-rate targeting regime is found to have lower exchange rate volatility on average, statistical significance is only observed for the real exchange rate. The effect of different monetary policy regimes rather than bilateral monetary policy on trade performance probably has higher policy relevance. Unlike the studies on the effect of a common currency or a direct peg on bilateral trade, the empirical study on the effects of various policy regimes on multilateral trade is relatively scanty. One exception is the evidence on the positive effect of currency union membership on multilateral trade in the working paper version of Frankel and Rose (2002). 


\section{Table 6. Monetary Policy Regimes and Effective Exchange Rate Volatility}

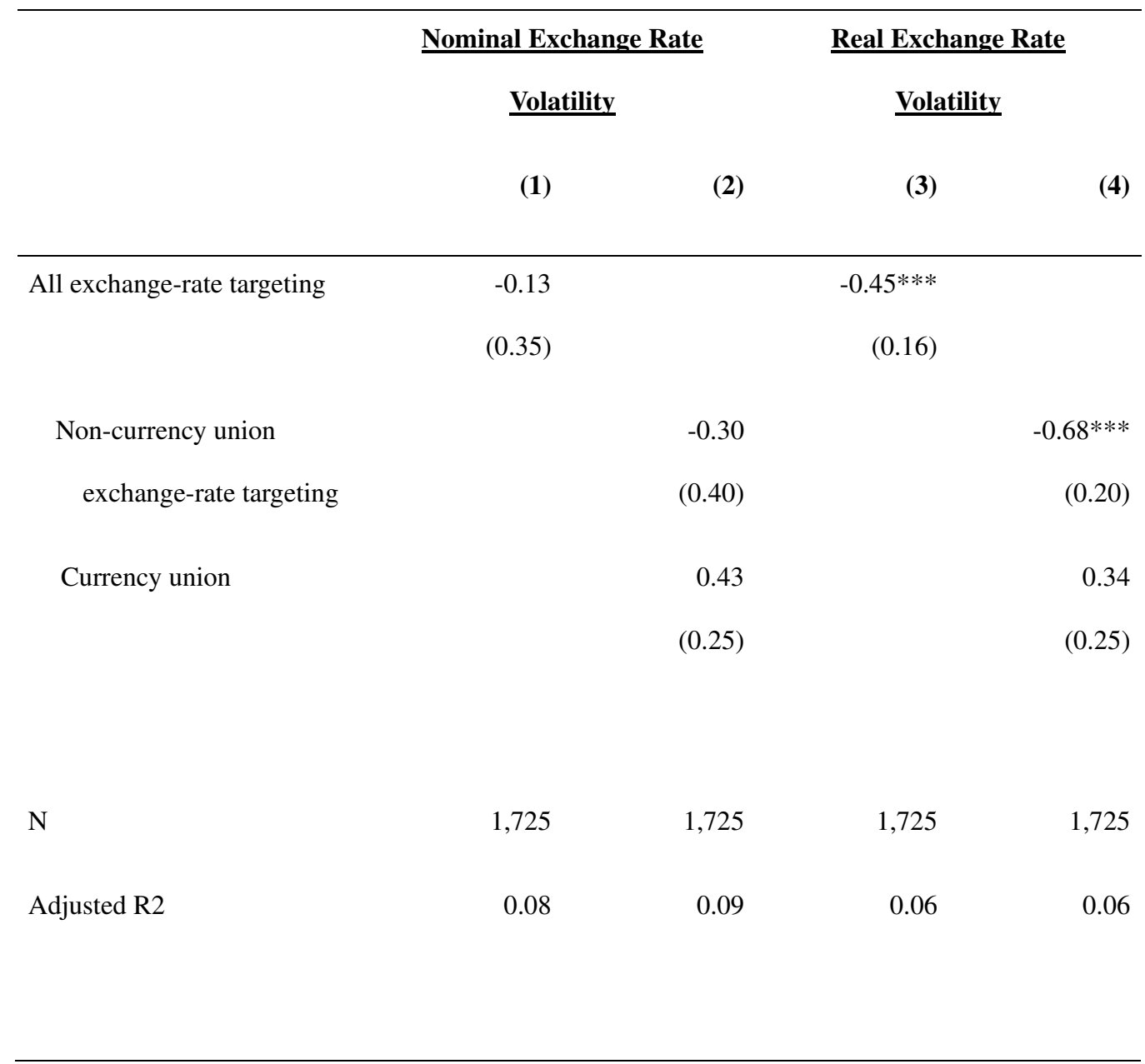

*** significant at $1 \%$

Results obtained from fixed effect model

Year effects are included but not reported

Standard errors are clustered at country level 
Table 7 presents the estimations for the multilateral trade performance of various monetary policy regimes. The results are estimated with both pooled OLS and fixed effect model with related control variables captured from the gravity model ${ }^{14}$. Results estimated with pooled OLS and fixed effect model in the first two columns show that the exchange-rate targeting regime as a whole fails to report any significant effects on multilateral trade against the inflation targeting regime.

The estimation in the third column split exchange-rate targeting regime into two subgroups of currency unions and non-currency unions. The result supports the finding in Frankel and Rose (2002) that currency unions have more trades. ${ }^{15}$ Exchange-rate targeting regime other than currency union, however, reports a lower level of multilateral trade than inflation targeting regime. The last two columns of Table 4 present the estimation results with two alternative specifications. Estimation in the fourth column replaces the nominal exchange rate volatility with the real exchange rate volatility, and the fifth column removes the exchange rate volatility from the specification to include the effect of monetary policy regimes on multilateral trade through the exchange rate channel. The last column reports the result of instrument variable estimation. The percentage of countries having exchange-rate targeting policy in the region of country $i$ is used as the instrument variable. This instrument variable, indeed, follows a similar rationale to the instrument variable used in the estimation with bilateral data. The main result on the trade performance of various monetary policy regimes in these alternative specifications and instrument variable estimation

\footnotetext{
${ }^{14}$ However, it should be emphasized that the equation for the effect of monetary policy regimes on trade at multilateral level is rather ad hoc and receives less theoretical support than the gravity model.

${ }^{15}$ The group for comparison, however, is the inflation targeting regime in this study rather than the floating regime in Frankel and Rose (2002).
} 
remains the same. This result, surprisingly, is consistent with the naïve comparison in the previous section.

Table 7. Monetary Policy Regimes and Multilateral Trade

\begin{tabular}{|c|c|c|c|c|c|c|}
\hline & \multicolumn{2}{|l|}{$\underline{\text { OLS }}$} & \multicolumn{3}{|c|}{ Fixed Effect } & \multirow[b]{2}{*}{ (6) } \\
\hline & (1) & (2) & (3) & (4) & (5) & \\
\hline \multirow[t]{2}{*}{ All exchange-rate targeting } & -0.08 & -0.03 & & & & \\
\hline & $(0.07)$ & $(0.03)$ & & & & \\
\hline Non-currency union & & & $-0.08 * *$ & $-0.07 * *$ & $-0.07 * *$ & $-0.21 * * *$ \\
\hline exchange-rate targeting & & & $(0.03)$ & $(0.03)$ & $(0.03)$ & $(0.04)$ \\
\hline Currency union & & & $0.14 * *$ & $0.13 * *$ & $0.14 * *$ & $0.14 * *$ \\
\hline membership & & & $(0.06)$ & $(0.06)$ & $(0.06)$ & $(0.06)$ \\
\hline Log of real gross domestic & $0.96^{* * *}$ & $0.94 * * *$ & $0.96^{* * *}$ & $0.94 * * *$ & $0.95^{* * *}$ & $0.96^{* * *}$ \\
\hline products & $(0.04)$ & $(0.06)$ & $(0.06)$ & $(0.07)$ & $(0.07)$ & $(0.07)$ \\
\hline \multirow[t]{2}{*}{ Log of land area } & $-0.13 * * *$ & & & & & \\
\hline & $(0.04)$ & & & & & \\
\hline \multirow[t]{2}{*}{ Island } & -0.16 & & & & & \\
\hline & $(0.14)$ & & & & & \\
\hline \multirow[t]{2}{*}{ Landlocked } & -0.15 & & & & & \\
\hline & $(0.10)$ & & & & & \\
\hline \multirow[t]{2}{*}{ Advanced economy } & 0.04 & & & & & \\
\hline & $(0.15)$ & & & & & \\
\hline Nominal exchange rate & $-0.06 * * *$ & $-0.02 * * *$ & $-0.03 * * *$ & & & $-0.03 * * *$ \\
\hline volatility & $(0.01)$ & $(0.01)$ & $(0.01)$ & & & $(0.01)$ \\
\hline
\end{tabular}




\begin{tabular}{|c|c|c|c|c|c|c|}
\hline Real exchange rate & & & & -0.01 & & \\
\hline volatility & & & & $(0.01)$ & & \\
\hline $\mathrm{N}$ & 1,725 & 1,725 & 1,725 & 1,725 & 1,725 & 1,725 \\
\hline Adjusted R2 & 0.94 & 0.71 & 0.72 & 0.71 & 0.71 & 0.71 \\
\hline Hausman (p-value) & & 0.00 & & & & \\
\hline
\end{tabular}

** significant at $5 \%, * * *$ significant at $1 \%$

Year effects are included but not reported

Standard errors are clustered at country level

\section{Conclusion}

The effects of a common currency and a direct peg relationship under fixed exchange rate on trade are well studied. The monetary policy of the floating rate regime, however, is usually ignored and thus the effect of other monetary policy regimes on trade remains unknown. In contrast to the absence of empirical study on this area, Bacchetta and Van Wincoop (2000) highlights the importance of well-defined alternative monetary policy regimes in trade using a full equilibrium model.

This paper attempts to fill the gap in this area using a new de facto classification of monetary policy regimes in Wong and Chong (2014). Using the two well-defined monetary policy regimes, inflation targeting and exchange-rate targeting as identified in the classification, the effect of inflation targeting monetary policy on trade is 
studied. The effects of a common currency and a direct peg relationship reported in this paper are highly consistent with previous studies. Furthermore, the main result provides evidence on the positive effect of inflation targeting policy on bilateral trade between two inflation targeting countries.

Even though the effect of inflation targeting policy on trade between inflation targeting countries is much more moderate than a direct peg under exchange-rate targeting regime ( $6 \%$ vs $21 \%$ ), the positive effect of inflation targeting regime could be shared by a much larger number of countries in the same regime. The effect of a direct peg on trade, however, is restricted to a single anchor country for exchange-rate targeting regime. This suggests that a stronger effect of a direct peg on trade does not necessarily result in a higher level of multilateral trade for exchange-rate targeting regime. Empirically, results of the fixed effect model suggest that inflation targeting regime has a higher level of multilateral trade than exchange-rate targeting regime excluding countries in currency union. 


\section{References:}

Adam, Christopher and Cobham, David. 2007. "Exchange Rate Regimes and Trade." The Manchester School, 75(s1): 44-63.

Anderson, James and Van Wincoop, Eric. 2003. "Gravity and Gravitas: A Solution to the Border Puzzle." American Economic Review, 93(1): 170-192.

Bacchetta, Philippe and Van Wincoop, Eric. 2000. "Does Exchange-Rate Stability Increases Trade and Welfare?" American Economic Review, 90(5): 1093 - 1109.

Berger, Helge and Nitsch, Volker. 2008. "Zooming Out: The Trade Effect of the Euro in Historical Perspective." Journal of International Money and Finance, 27: 1244-1260.

Frankel, Jeffrey. 2008. "The Estimated Effects of the Euro on Trade: Why Are They Below Historical Effects of Monetary Unions Among Smaller Countries.” NBER working paper no. 14542 .

Frankel, Jeffrey and Rose, Andrew. 2002. "An Estimate of the Effect of Common Currencies on Trade and Income.” Quarterly Journal of Economics, 437-466.

Glick, Reuven and Rose, Andrew. 2002. "Does a Currency Union Affect Trade? The Time-series Evidence” European Economic Review, 46: 1125-1151.

Husain, Aasim, Mody, Ashoka and Rogoff, Kenneth. 2005. "Exchange Rate Regime Durability and Performance in Developing versus Advanced Economies." Journal of Monetary Economics, 52(1): 35-64.

Klein, Michael and Shambaugh, Jay. 2006. "Fixed Exchange Rates and Trade." Journal of International Economics, 70: 359-383.

Klein, Michael and Shambaugh, Jay. 2008. "The Dynamics of Exchange Rate 
Regimes: Fixes, Floats, and Flips.” Journal of International Economics, 75(1): 70-92.

Levi-Yeyati, Eduardo and Federico Sturzenegger. 2005. “Classifying Exchange Rate Regimes: Deeds vs. Words.” European Economic Review, 49: 1603-1635.

Lopez-Cordova and Meissner. 2003. "Exchange-Rate Regimes and International Trade: Evidence from The Classical Gold Standard Era.” American Economic Review, 93(1): 344-353.

Micco, Alejandro, Stein, Ernesto and Ordoñez, Guillermo. 2003. "The Currency Union Effect on Trade: Early Evidence from EMU.” Economic Policy, 18(37), 315-356.

Rose, Andrew. 2000. “One Money, One Market: The Effect of Common Currencies on Trade". Economic Policy, 8-45.

Rose, Andrew. 2007. “A Stable International Monetary System Emerges: Inflation Targeting is Bretton Woods, Reversed." Journal of International Money and Finance, 26(5): 663-681.

Rose, Andrew and Spiegel, Mark. 2011. "The Olympic Effect." The Economic Journal, 121(553): 652-677.

Rose, Andrew and Van Winccop, Eric. 2001. "National Money as a Barrier to International Trade: The Real Case for Currency Union." AEA Papers and Proceedings, 91(2): 170-192.

Silva, JMC Santos and Tenreyro, Silvana. 2006. "The Log of Gravity." The Review of Economics and Statistics, 88(4): 641-658.

Tenreyro, Silvana. 2007. "On the Trade Impact of Nominal Exchange Rate Volatility." Journal of Development Economics, 82(2): 485-508.

Wong, Kin Ming and Chong, Terence Tai-Leung. 2014. “A Tale of Two Regimes: 
Classifying and Revisiting the Monetary Policy Regimes." Working Paper No.

25, Institute of Global Economics and Finance, The Chinese University of Hong Kong. 


\section{Appendix A: A Note on the de facto Classification of Monetary Policy Regimes}

In Wong and Chong (2014), we provide a de facto classification of monetary policy regimes for 228 countries reported to the IMF over the post-Bretton Woods period from 1974 to 2009. Upon excluding 3,902 observations with unavailable data for at least one of the classification variables ${ }^{16}$ and 161 outliers in the data, the remaining 3,917 observations are classified using the K-mean cluster analysis.

Monetary policy regimes under classification are the two typical monetary policy frameworks, the exchange-rate targeting and inflation targeting policy regime. Volatility of three economic variables, namely interest rate, exchange rate and inflation are used as the classification variables and Table A1 presents their relative volatility under the two targeting policies derived from a basic New Keynesian model following Galí (2008).

Table A1. Relative volatility of economic variables under two regimes

\begin{tabular}{llllcc}
\hline Magnitude & $\underline{\text { Openness }}$ & Targeting & $\begin{array}{c}\text { Interest rate } \\
\text { Volatility }\end{array}$ & $\begin{array}{c}\text { Exchange } \\
\text { rate Volatility }\end{array}$ & $\begin{array}{c}\text { Inflation } \\
\text { Volatility }\end{array}$ \\
\cline { 1 - 1 }$\frac{\text { of Shock }}{\text { High }}$ & Low & Inflation & High & High & Low \\
High & Low & Exchange Rate & High & Low & High \\
High & High & Either & High & Low & Low \\
Low & Either & Either & Low & Low & Low \\
\hline
\end{tabular}

The classification procedure follows several steps. Following Levy-Yeyati and Sturzenegger (2005), two percent of the upper tail of observations of each classification variables is removed from the data. These outliers are classified into alternative monetary policy regimes in the later step. The remaining observations are range standardized and classified into the four clusters described in Table A1. As described in Table A1, the classification results in two inconclusive categories: the first shows evidence of monetary policy intervention, but policy target is unclear; the

\footnotetext{
${ }^{16}$ In some cases, data of a country may not be available since the country does not exist in the entire sample period. Out of the 228 countries reported in the list of IMF, 186 countries have been classified at least for one period.
} 
second has low volatility in both instrument and target variables because of less intensity of underlying shock.

Observations in these two inconclusive clusters are further analyzed with restandardized variables. For observations in the first inconclusive cluster, they are further classified into alternative monetary policy regimes in a second stage. In the second stage, only the two target variables are used for classification as the data to be classified have already shown clear evidence of policy intervention in the previous stage. For the second inconclusive cluster, another round of classification with the four described clusters using all three classification variables is performed to account for different levels of underlying macroeconomic volatility, as suggested in LevyYeyati and Sturzenegger (2005). Finally, three rounds of the two-stage classification have been performed with 1,275 observations left in the inconclusive group.

In the final step, observations that remain unclassified are further analyzed. In addition to the 1,275 inconclusive observations in the cluster analysis, this also includes the 161 outliers and 3,902 observations with unavailable classification variables that are excluded from the classification procedure. The classification of the 161 outliers is straightforward and most of them can be assigned to one of the cluster centers identified in the cluster analysis with minimum distance. The ad hoc classification of the 1,275 inconclusive observations and 3,902 observations with unavailable variables is based on the methodology of Levy-Yeyati and Sturzenegger (2005). An observation is assigned to the exchange rate targeting regime if it (i) has zero volatility in the exchange rate, or (ii) is identified as a fixed exchange rate regime by the IMF and has less than $0.1 \%$ volatility in the exchange rate. Similar to Levy-Yeyati and Sturzenegger (2005), the $0.1 \%$ volatility in the exchange rate places a comfortable buffer from the minimum exchange rate volatility of the inflation targeting regime (which is $0.2 \%$ ). In this sense, countries without an independent legal tender including members of Euro zone are also classified as exchange rate targeting. Finally, the classification has identified 2,957 country-year observations in the exchange rate targeting regime and 1,489 observations in the inflation targeting regime. The classification procedure is depicted in Figure A1. 


\section{Figure A1. The Classification Procedure}

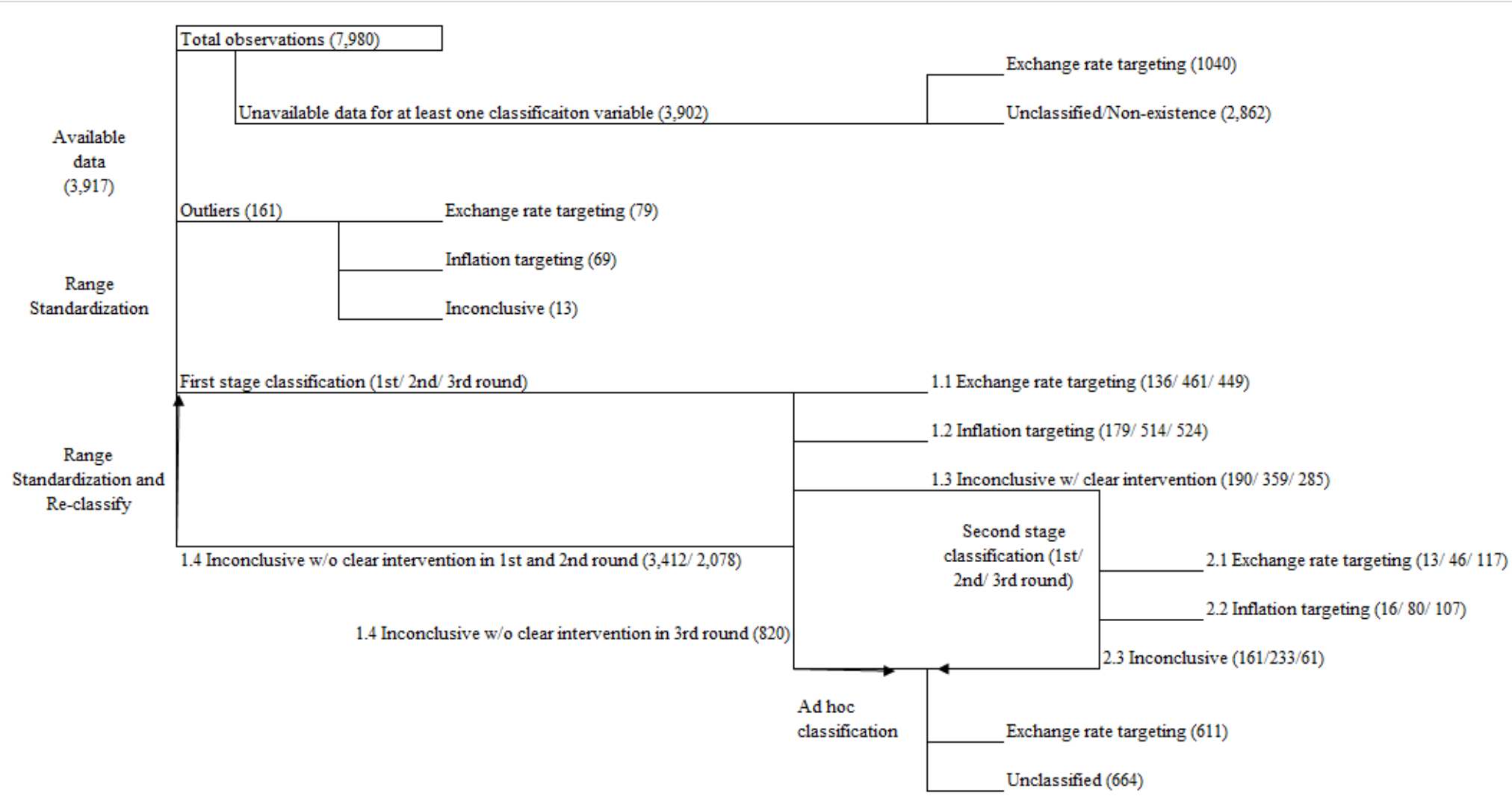

